Research Article

\title{
The Antibacterial Activity of Crude Extracts of Secondary Metabolites from Bacterial Endophytes Associated with Dicoma anomala
}

\author{
Sephokoane Cindy Makuwa (D) and Mahloro Hope Serepa-Dlamini \\ Department of Biotechnology and Food Technology, Faculty of Science, University of Johannesburg, Doornfontein Campus, \\ Johannesburg, South Africa
}

Correspondence should be addressed to Mahloro Hope Serepa-Dlamini; hopes@uj.ac.za

Received 27 May 2020; Revised 28 January 2021; Accepted 27 March 2021; Published 13 April 2021

Academic Editor: Clemencia Chaves Lopez

Copyright ( 2021 Sephokoane Cindy Makuwa and Mahloro Hope Serepa-Dlamini. This is an open access article distributed under the Creative Commons Attribution License, which permits unrestricted use, distribution, and reproduction in any medium, provided the original work is properly cited.

Endophytic bacteria isolated from medicinal plants are recognized valuable sources of novel bioactive compounds with various activities such as antimicrobial, anticancer, and antiviral. In this study, eleven bacterial endophytes were isolated from surface sterilized roots and leave tissues, of medicinal plant Dicoma anomala. The bacterial endophytes were identified by sequencing the $16 \mathrm{~S}$ rRNA gene, and belong to five genera viz Bacillus, Staphylococcus, Stenotrophomonas, Enterobacter, and Pantoea. The dominant genera were Bacillus with five strains, Staphylococcus with two strains, and Stenotrophomonas with two strains. The crude extracts of seven selected bacterial endophytes indicated antimicrobial activity against five pathogenic strains Escherichia coli (ATCC 25922), Bacillus cereus (ATCC 10876), Staphylococcus aureus (NCTC 6571), Pseudomonas aeruginosa (ATCC 27853), and Klebsiella oxytoca (ATCC 13182), with significant inhibition concentration ranging from $0.312 \mathrm{mg} / \mathrm{ml}$ to $0.625 \mathrm{mg} / \mathrm{ml}$. Finally, based on the data analysis of the crude extracts of the endophytes, we identified bioactive secondary metabolites with reported biological activities such as antimicrobial, anti-inflammatory, and antioxidant properties with biotechnological applications in medicine, agriculture, and other industries. This study reported for the first time bacterial endophytes associated with $D$. anomala, with antimicrobial activity against bacterial pathogens.

\section{Introduction}

Medicinal plants are a source of biologically active compounds for novel drug development [1]. Historically, plants with healing properties were utilized in continents such as Asia and Africa, to treat diseases such as diarrhoea, headaches, and fevers [1]. In modern days, approximately $80 \%$ of the world's population, especially within the developing countries, rely on herbal medicines from traditional healers to treat various diseases [2].

The use of medicinal plants for novel drug discovery is however a limiting factor, because at times high amounts of the plant materials are required for clinical studies before the products even make it to the market; moreover, some compounds are derived from endangered or endemic plant species. One of the advances made in addressing these concerns was the discovery of microorganisms called endophytes living within plants, which produce the same or similar compounds like those produced by their plant hosts $[1,3]$. Endophytes are either fungi or bacteria and reside inside the plant tissues without causing any harm. Of interest in the current study are bacterial endophytes. Endophytic bacteria belong to various genera and many of the biological active substances extracted from endophytic bacteria are reported to be novel with various bioactivities [4]. Microbes are a good source for extraction of biologically active compounds due to their ease of isolation, growth, and inability to impact negatively on the environment and agricultural productivity $[5,6]$. From a commercial and industrial point of view, it is easier to expand microbial fermentation which can ultimately increase production of biologically active compounds. Thus, microbes associated 
with medicinal plants present an opportunity for isolating novel biologically active compounds, with benefit of preserving medicinal plants, as minimal plant material is required for endophyte isolation.

Endophytes significantly ameliorate plant growth by a number of mechanisms including increase of uptake of essential nutrients such as phosphate, ammonia, and nitrogen, producing phytohormones such as indole-3-acetic acid and gibberellin, and inhibiting pathogen proliferation through the production of secondary metabolites with antimicrobial activity [1]. Moreover, many antimicrobial compounds produced by bacterial endophytes belong to several structural classes such as peptides, alkaloids, steroids, quinines, terpenoids, phenols, and flavonoids with various applications [7]. Therefore, there is a worldwide renewed scientific effort to isolate endophytes and study their natural products, which play a vital role as antibacterial, antiviral, antioxidant, antiarthritic, and antidiabetic and as immunesuppressive compound.

Dicoma anomala is a perennial herb with an underground tuber; it belongs to the family Asteraceae. Dicoma anomala is mostly distributed in southern African countries; in South Africa it is found in Limpopo, North-West, Gauteng, Mpumalanga, Free State, Northern Cape, and KwaZulu-Natal provinces [8,9]. Dicoma anomala roots and leaves have ethnomedicinal uses for ailments such as colds and coughs, fevers, ulcers, labour pains, dysentery, stomach problems, dermatosis, sores, and wounds [8]. Literature indicates that D. anomala is known to produce secondary metabolites including acetylenic compounds, diterpene, flavonoids, phenolic acids, phytosterols, saponins, sesquiterpene lactones, tannins, and triterpenes [10] and a study reported by [8] has shown that these compounds possess antimicrobial, antiinflammatory, antioxidant, antiplasmodial, anticancer, and cytotoxicity, antihyperglycaemic, and hepatoprotective properties. Consequently, extracting and identifying novel secondary bioactive compounds from bacterial endophytes associated with this plant could become the alternative option to overcome levels of drug resistance and conserve the plant species eventually.

This study was undertaken to isolate and identify bacterial endophytes from $D$. anomala, which is a less explored medicinal plant with ethno-botanical history. In addition, the selected endophyte's secondary metabolite crude extracts were assayed for antibacterial activity and further identification of the secreted secondary metabolites using Gas Chromatography High-Resolution Time-of-Flight Mass Spectrometry (GC-HRTOF-MS). To the best of our knowledge, there has been no previous work published on antimicrobial activity of bacterial endophytes isolated from medicinal plant D. anomala.

\section{Materials and Methods}

2.1. Plant Sample Collection and Identification. Dicoma anomala plant material was collected in April 2018 from the natural habitat with slit soil type in Eisleben, Limpopo province, South Africa (23.52 S 29.824E). Whole plants including roots were placed in sterile polyethylene bags and transported to the laboratory under $4^{\circ} \mathrm{C}$. The identification of the plant material was carried out at the University of Johannesburg Herbarium (JRAU) and a sample specimen of the plant material was deposited JRAU with voucher specimen number Serepa-Dlamini 204 and species name Dicoma anomala. The remaining collected plant material was immediately processed in the laboratory.

2.2. Isolation of Endophytic Bacteria. Immediately after collection, in the lab, endophytic bacteria were isolated from fresh leaves and roots of the plant following the procedure described by [11]. In brief, plant parts were washed thoroughly with running tap water and surface sterilized with $70 \%$ ethanol for 5 minutes, followed by a rinse with sterile distilled water, soaking in $2 \% \mathrm{NaClO}$ for 3 minutes, and final rinse with sterile distilled water 3 times and the final wash water was plated on to nutrient agar plates as control. The surface-disinfected plant parts were crushed using sterile mortar and pestle and macerated with phosphate buffer $(8 \mathrm{~g}$ $\mathrm{NaCl}, 0.2 \mathrm{~g} \mathrm{KCl}, 1.44 \mathrm{~g} \mathrm{Na} 2 \mathrm{HPO}_{4}$, and $\mathrm{KH}_{2} \mathrm{PO}_{4}$ at $\mathrm{pH} 7.4$ ). Following sterile techniques, the homogenate was streaked on nutrient agar plates and incubated together with the control plates at $28^{\circ} \mathrm{C}$ for $2-7$ days. The plates were observed for growth daily; grown colonies were subcultured several times until pure single colonies were obtained. Confirmation of culture purity of the strains was selected on the basis of phenotypic characteristics such as colony morphology, colony colour, colony size, and Gram reaction. In total, 11 isolates were selected for this study and preserved in $30 \%$ glycerol stock $(\mathrm{v} / \mathrm{v})$ solution for long-term storage at $-80^{\circ} \mathrm{C}$.

\subsection{Genotypic Characterization of the Bacterial Endophytes}

2.3.1. Genomic DNA Extraction. Genomic DNA was extracted from pure solid colonies using the Zymo Research Fungal/Bacterial DNA MiniPrep Kit as per manufacturer's protocol (Zymo Research, USA). The extracted DNA was electrophoresed on $1 \%$ agarose gel and the concentration was determined using the Nanodrop Spectrophotometer (Thermo Fisher Scientific, USA).

2.3.2. 16S rRNA Gene Sequence Analysis. Using Polymerase chain reaction (PCR), DNA of each bacterial isolate was amplified using 16S rRNA gene universal primers described by [12]. The amplification of the $16 \mathrm{~S}$ rDNA was carried out in a reaction tube with a final volume of $25 \mu \mathrm{L}$ containing $2.5 \mu \mathrm{L}$ $(<1,000 \mathrm{ng})$ of template DNA, $2.5 \mu \mathrm{L}(10 \mu \mathrm{M})$ of each forward primer $5^{\prime}$-AGAGTTTGATCCTGGCTCAG- $3^{\prime} \mathrm{F}$ and reverse primer $5^{\prime}$-AAGGAGGTGATCCAAGCCGCA-3' $\mathrm{R}, 4 \mu \mathrm{L}$ of 2X PCR Master mix with standard buffer $(20 \mathrm{mM}$ Tris-HCI, $1.8 \mathrm{mM} \mathrm{MgCl}_{2}, 22 \mathrm{mM} \mathrm{NH}_{4} \mathrm{Cl}, 22 \mathrm{mM} \mathrm{KCl}, 0.2 \mathrm{mM}$ dNTPs, $5 \%$ glycerol, 0.06\% IGEPAL ${ }^{\circledR}$ CA-630, 0.05\% Tween ${ }^{\circledR} 20,25$ units/mL One Taq ${ }^{\circledR}$ DNA polymerase) and final volume was filled up $25 \mu \mathrm{L}$ with nuclease-free water. A negative control (PCR mix without DNA) was included in all PCR experiments. Using MyCycler ${ }^{\mathrm{TM}}$ Thermal Cycler (Bio-Rad, USA), the PCR reaction conditions were as follows: initial 
denaturation at $94^{\circ} \mathrm{C}$ for 3 minutes, followed by 35 cycles of denaturation at $94^{\circ} \mathrm{C}$ for 1 minute, annealing at $48^{\circ} \mathrm{C}$ for 1 minute and extension at $72^{\circ} \mathrm{C}$ for 2 minutes, and a final extension of $72^{\circ} \mathrm{C}$ for 10 minutes. The PCR products were purified with ExoSAP-it ${ }^{\mathrm{TM}}$ (Thermo Fisher Scientific, USA) and sent for sequencing at a commercial service provider Inqaba Biotechnical Industries (Pty) Ltd, Pretoria, South Africa.

2.3.3. Phylogenetic Analysis. Raw sequence data were used to create consensus sequences using BioEdit Sequence Alignment Editor version 7.2.6 [13]. The obtained 16S rDNA sequences were subjected to Basic Local Alignment Search Tool (BLAST) analysis against the rRNA sequence database (Bacteria and Archaea) at the National Centre for Biotechnology Information (NCBI) (available at http://blast. ncbi.nlm.nih.gov) to compare with the closest related bacterial species. Only bacterial species with highest similarity identity percentage (90-100\%) were selected for phylogenetic analysis. Phylogenetic trees were constructed using MEGA 7 [14] after alignment with MUSCLE [15]. DNA substitutions were done according to the Tamura Nei model. Phylogenetic relatedness of the endophytes with other close relatives was clustered using maximum-likelihood method. Bootstrap replications of 1000 were used as the statistical confidence of the nodes in the phylogenetic trees. Outgroups were considered to support differences among species. The nucleotide sequences of $16 \mathrm{~S}$ rRNA genes were deposited to GenBank ((https://www.ncbi.nlm.nih.gov/genbank/) and assigned accession numbers.

2.3.4. Nucleotide Sequence Accession Numbers. The bacterial isolates were assigned the following accession numbers: MN029049 (Stenotrophomonas sp. strain MHSD20), MN029050 (Enterobacter sp. strain MHSD22), MN029051 (Staphylococcus sp. strain MHSD24), MN029052 (Staphylococcus sp. strain MHSD26), MN029053 (Bacillus sp. strain MHSD28), MN078165 Bacillus sp. strain MHSD13, MN078166 (Bacillus sp. strain MHSD14), MN078167 (Bacillus sp. strain MHSD16), MN078168 (Bacillus sp. strain MHSD17), and MN093331 (Pantoea sp. strain MHSD15).

\subsection{Antimicrobial Assay Minimum Inhibitory Concentration (MIC)}

2.4.1. Preparation of Bacterial Endophyte's Secondary Metabolite Crude Extracts. Secondary metabolites were extracted from selected isolated bacterial endophytes; care was taken to include species which were not assayed previously. The selected species included Stenotrophomonas sp. strain MHSD20, Enterobacter sp. strain MHSD22, Staphylococcus sp. strain MHSD26, Bacillus sp. strain MHSD28, Stenotrophomonas sp. strain MHSD12, Bacillus sp. strain MHSD14, and Pantoea sp. strain MHSD15. The bacterial endophytes were cultured in 1L Luria Broth (LB) for 7 days at $28^{\circ} \mathrm{C}$ on a shaking incubator at $180 \mathrm{rpm}$. After cultivation, $2 \mathrm{~g} / \mathrm{L}$ of sterilized Amberlite ${ }^{\circledR}$ XAD-7-HP resin (Sigma-
Aldrich, Darmstadt, Germany) was added to the cultures and shaken for 2 hours at $180 \mathrm{rpm}$, to absorb the secondary metabolites. The resin was filtered through a cheesecloth and eluted 3 times with $200 \mathrm{~mL}$ of acetone. The acetone was evaporated using rotary evaporator. The remaining liquid containing the crude extracts was further extracted 3 times with ethyl acetate in a 1:1 ratio (v/v) and the ethyl acetate was evaporated and concentrated with rotary evaporator. The crude extracts containing the secondary metabolites were transferred to $20 \mathrm{~mL}$ beakers and covered with foil and stored at room temperature to dry out until further analysis.

\subsubsection{Minimum Inhibitory Concentration (MIC). Minimum} inhibitory concentration studies of the bacterial endophyte's crude extracts were performed according to the method by [16] with some modifications. Briefly, stock solutions of the extracts were prepared by dissolving $0.02 \mathrm{~g}$ in $1 \mathrm{~mL}$ dimethyl sulfoxide (DMSO) to produce a final concentration of $20 \mathrm{mg} / \mathrm{mL}$, which were then serially diluted to concentrations of $10 \mathrm{mg} / \mathrm{mL}, 5 \mathrm{mg} / \mathrm{mL}, 2.5 \mathrm{mg} / \mathrm{mL}, 1.25 \mathrm{mg} / \mathrm{mL}$, $0.625 \mathrm{mg} / \mathrm{mL}$, and $0.312 \mathrm{mg} / \mathrm{mL}$ using Mueller-Hinton broth. The pathogenic test strains used were Gram-negative bacteria Escherichia coli (ATCC25922), Pseudomonas aeruginosa (ATCC27853), and Klebsiella oxytoca (ATCC13182) and Gram-positive bacteria Staphylococcus aureus (NCTC6571) and Bacillus cereus (ATCC10876). Using McFarland 0.5 standard, $50 \mu \mathrm{L}$ of each pathogen was inoculated in $15 \mathrm{~mL}$ of Muller-Hinton broth and incubated at $37^{\circ} \mathrm{C}$ for 24 hours. Following aseptic techniques in 96 well microtitre plates, $100 \mu \mathrm{L}$ of pathogenic test strains was added horizontally and $100 \mu \mathrm{L}$ of the diluted crude extract concentrations was added vertically starting from high to low concentrations. Negative controls $[100 \mu \mathrm{L}$ DMSO and $100 \mu \mathrm{L}$ sterile Mueller-Hinton broth, 1:1 ratio (v/v)] and positive control $1 \mathrm{mg} / \mathrm{mL}$ Streptomycin antibiotic (SigmaAldrich, Switzerland) were added vertically in the wells subsequent to those with low concentrations. The microtitre plates were incubated at $37^{\circ} \mathrm{C}$ for 24 hours. The MIC assays were conducted in triplicates. After incubation, ten microliters of resazurin sodium salt solution $[0.02 \%(\mathrm{w} / \mathrm{v})]$ was added to the wells as an indicator of microbial growth and incubated for another 2 hours. The ability of the crude extracts to inhibit pathogenic strains was indicated by no colour change of resazurin sodium salt solution (remains blue) and the colour change from blue to pink after incubation indicated no bacterial inhibition. The MIC (lowest concentration of each extract displaying no visible growth) values were visually determined.

\subsection{Metabolite Fingerprinting Analysis Using GC-HTOF-MS.} Metabolite profiling of the crude extracts was performed at a two-dimensional mode using Pegasus GC-HRTOF-MS system (Leco Corporation St. Joseph, MI, USA). One microliter of each sample was injected and helium was used as the carrier gas at $1 \mathrm{~mL} / \mathrm{min}$ flow rate. The primary column was a Restek Rtx-5siLMS ( $30 \mathrm{~m} \times 250 \mu \mathrm{m}$ d.f.) and the secondary column was Restek Rxil7siLMS $(1 \mathrm{~m} \times 250 \mu \mathrm{m} \times 0.25 \mu \mathrm{m}$ d.f. $)$. The GC oven temperature was 
maintained at $60^{\circ} \mathrm{C}$ for 1 minute, then ramped to $330^{\circ} \mathrm{C}$ at $10^{\circ} \mathrm{C} / \mathrm{min}$, and thereafter held for 5 minutes at transfer line temperature of $280^{\circ} \mathrm{C}$. The inlet temperature was $250^{\circ} \mathrm{C}$. The MS was optimized at $-70 \mathrm{eV}$ (electron energy) with an ion source at $250^{\circ} \mathrm{C}$. The collected mass range was 40 to $660 \mathrm{~m} / z$ with an acquisition rate of 10 spectra/second. The generated data was analysed using $\mathrm{ChromaTOF}^{\circledR}$ software. The NCBI Pubchem database, available at https://pubchem.ncbi.nlm. nih.gov/ [17], was used to interpret functional groups and PASS online database, available at http://www.way2drug. $\mathrm{com} /$ passonline, was used to predict the biological activities of the metabolites [18].

2.6. Statistical Analysis. The MIC of the crude's extracts was statistically validated by one-way analysis of variance (ANOVA) using in Microsoft Excel 2016. Significant differences at $p \leq 0.05$ were considered statistically different.

\section{Results and Discussion}

3.1. Morphological Identification. In this study, a total of 11 bacterial endophytes from 5 genera belonging to two phyla (Firmicutes and Proteobacteria) were isolated from surface sterilized leaves and roots of a healthy medicinal plant D. anomala. Majority of the endophytic bacteria were isolated from the roots with 6 isolates, followed by the leaves with 5 isolates (Table 1). A great morphological diversity was observed where each isolate showed unique characteristics in terms of colony colour, shape, size, and margins. The isolates were grouped into two distinct classes based on Gram staining technique, The Gram-positive bacteria (7 isolates) and the Gram-negative bacteria (4 isolates).

The surface sterilization technique was adequate as the control plates had shown no microbial growth. Therefore, bacterial colonies that grew on the media were regarded as endophytic bacteria of $D$. anomala. To the best of our knowledge, this is the first report on isolation of bacterial endophytes from D. anomala. Bacillus genus occurred in both leaves and root samples, having a larger occurrence with 5 strains. These results are comparable to various studies that have reported different genera of Firmicutes and Proteobacteria which included Bacillus [19], Staphylococcus [20], Stenotrophomonas [21], Enterobacter [22], and Pantoea [23]; bacterial species from these genera seem to be occurring as bacterial endophyte communities of many plants.

The distribution and diversity of bacterial endophytes in plants are influenced by many factors including host plant species, age and type of the plant tissue, geographical and habitat distribution, sampling season, surface sterilization method, growth media, and culture conditions [24]. In this study, the plant material was collected from a slit soil in April 2018, we utilized nutrient agar for growth and isolation of the bacterial endophytes, and as such this resulted in limited number of identified bacterial endophytes.

3.2. Molecular Identification and Phylogenetic Analysis of the Bacterial Endophytes. The 16S rRNA gene sequence-based identification is a rapid method for molecular identification of bacterial species. Firmicutes and Proteobacteria were found among the isolated endophytic bacteria (Table 2). The bacterial isolates were classified into five genera which include Bacillus with 5 five isolates, Staphylococcus with 2 isolates, Stenotrophomonas with 1 isolate, Enterobacter with 1 isolate, and Pantoea with 1 isolate, indicating Bacillus as the most dominant genus. The $16 \mathrm{~S}$ rDNA sequences obtained were submitted to NCBI and assigned the accession numbers provided in Table 2. Each genus was analysed in separate phylogenetic trees (Figures 1-5).

Staphylococcus sp. strain MHSD24 and MHSD26 sequences were aligned with strains of Staphylococcus genus, and Escherichia coli AE-1 (AB269763) was used as an outgroup (Figure 1). Strain MHSD24 was closely related to Staphylococcus warneri MK791673 with 98.29\% similarity whilst strain MHSD26 was closest to Staphylococcus pasteuri MK875469 with 97.44\% similarity (Table 2). Phylogenetic analysis shows that strain MHSD26 had a polyphyletic cluster with Staphylococcus pasteuri DCo1 and S. warneri BPB17, and strain MHSD24 also had a polyphyletic relationship with S. warneri PSB16. Numbers above or below the nodes indicate bootstrap values generated after 1000 replications.

Enterobacter sp. strain MHSD22 was closely related to Enterobacter ludwigii KU054383 with 97.48\% similarity (Table 2) and phylogenetic analysis showed strain MHSD22 had polyphyletic relationship with closely related Enterobacter species; Streptococcus mitis (AY360354) was used as an outgroup (Figure 2).

Stenotrophomonas strain MHSD20 and MHSD12 were aligned with closely related species of Stenotrophomonas genus, and Escherichia coli AE-1 (AB269763) was used as an outgroup taxon (Figure 3). Strain MHSD20 was closely related to Stenotrophomonas maltophilia (KM279660) with $98.55 \%$ similarity and strain MHSD12 was closely related to Stenotrophomonas maltophilia (MK734043) with 96.85\% similarity (Table 2). Phylogenetically, both strains showed high similarity among themselves, having a polyphyletic relationship with closely related Stenotrophomonas species (Figure 3). Pantoea sp. strain MHSD15 had a polyphyletic relationship with closely related species (Figure 4) and it had a $92.70 \%$ similarity with Pantoea sp. (MH769026) (Table 2).

Similarly, the sequences from that of Bacillus sp. strain MHSD28 were closely related to Bacillus cereus (MK503979) with $97.88 \%$ similarity, Bacillus sp. strain MHSD13 was closely related to Bacillus infantis (MK850860) with $97.33 \%$ similarity, Bacillus sp. strain MHSD14 was closely related to Bacillus thuringiensis (LT838181) with 97.68\% similarity, Bacillus sp. strain MHSD16 was closely related to Bacillus sp. (EUC01244) with $90.96 \%$ similarity, and Bacillus sp. strain MHSD17 was closely related to Bacillus cereus (KJ935725) with $98.15 \%$ similarity as indicated in Table 2. Phylogenetic analysis showed sister relationship between strain MHSD28 and MHSD16, strain MHSD17 and MHSD14 formed a polyphyletic relationship with related Bacillus species, and MHSD13 also had a polyphyletic relationship with closely related species (Figure 5).

The isolated bacterial endophytes were identified to genus level using the 16S rRNA gene phylogenetic analysis; we suggest sequencing other genes other than the $16 \mathrm{~S}$ rRNA 
TABLE 1: Morphological characteristics of bacterial endophytes isolated from leaves and roots tissues of Dicoma anomala.

\begin{tabular}{|c|c|c|c|c|c|}
\hline Plant part & Bacterial sample code & Assigned isolate name & Phyla & ${ }^{*}$ Gram reaction & Cell shape \\
\hline \multirow{5}{*}{ Leaves } & SC10L & Stenotrophomonas sp. strain MHSD20 & Proteobacteria & $-\mathrm{ve}$ & Rods \\
\hline & SC7L & Enterobacter sp. strain MHSD22 & Proteobacteria & - ve & Rods \\
\hline & MS3L & Staphylococcus sp. strain MHSD24 & Firmicutes & +ve & Cocci \\
\hline & MS4L & Staphylococcus sp. strain MHSD26 & Firmicutes & + ve & Cocci \\
\hline & MS8L & Bacillus sp. strain MHSD28 & Firmicutes & +ve & Rods \\
\hline \multirow{6}{*}{ Roots } & SC4R & Stenotrophomonas sp. strain MHSD12 & Proteobacteria & - ve & Rods \\
\hline & SC1R & Bacillus sp. strain MHSD13 & Firmicutes & +ve & Rods \\
\hline & SC2R & Bacillus sp. strain MHSD14 & Firmicutes & $+\mathrm{ve}$ & Rods \\
\hline & SC5R & Pantoea sp. strain MHSD15 & Proteobacteria & $-\mathrm{ve}$ & Rods \\
\hline & MS3R & Bacillus sp. strain MHSD16 & Firmicutes & + ve & Rods \\
\hline & MS10 R & Bacillus sp. strain MHSD17 & Firmicutes & +ve & Rods \\
\hline
\end{tabular}

${ }^{*}$ Gram reaction: $-\mathrm{ve}=$ Gram-negative; +ve = Gram-positive.

TABLE 2: NCBI BLAST 16S rRNA gene sequences of bacterial endophytes isolated from Dicoma anomala.

\begin{tabular}{|c|c|c|c|c|c|}
\hline \multirow[b]{2}{*}{ Assigned bacterial name } & \multirow[b]{2}{*}{$\begin{array}{l}\text { Assigned GenBank } \\
\text { accession number }\end{array}$} & \multicolumn{4}{|c|}{ NCBI blast results } \\
\hline & & $\begin{array}{l}\text { Closest related species with } \\
\text { accession number }\end{array}$ & $\begin{array}{c}\text { Query } \\
\text { coverage \% }\end{array}$ & $\begin{array}{c}E- \\
\text { value }\end{array}$ & $\begin{array}{c}\text { Identity } \\
\text { similarity \% }\end{array}$ \\
\hline $\begin{array}{l}\text { Stenotrophomonas sp. strain } \\
\text { MHSD20 }\end{array}$ & MN029049 & $\begin{array}{c}\text { Stenotrophomonas maltophilia } \\
\text { KM279660 }\end{array}$ & 100 & 0.0 & 98.55 \\
\hline $\begin{array}{l}\text { Enterobacter sp. strain } \\
\text { MHSD } 22\end{array}$ & MN029050 & Enterobacter ludwigii KU054383 & 100 & 0.0 & 97.48 \\
\hline $\begin{array}{l}\text { Staphylococcus sp. strain } \\
\text { MHSD24 }\end{array}$ & MN029051 & Staphylococcus warneri MK791673 & 100 & 0.0 & 98.29 \\
\hline $\begin{array}{l}\text { Staphylococcus sp. strain } \\
\text { MHSD26 }\end{array}$ & MN029052 & Staphylococcus pasteuri MK875469 & 100 & 0.0 & 97.44 \\
\hline Bacillus sp. strain MHSD28 & MN029053 & Bacillus cereus MK503979 & 100 & 0.0 & 97.88 \\
\hline $\begin{array}{l}\text { Stenotrophomonas sp. strain } \\
\text { MHSD12 }\end{array}$ & MN078164 & $\begin{array}{c}\text { Stenotrophomonas maltophilia } \\
\text { MK734043 }\end{array}$ & 100 & 0.0 & 96.85 \\
\hline Bacillus sp. strain MHSD13 & MN078165 & Bacillus infantis MK850860 & 100 & 0.0 & 97.33 \\
\hline Bacillus sp. strain MHSD14 & MN078166 & Bacillus thuringiensis LT838181 & 100 & 0.0 & 97.68 \\
\hline Pantoea sp. strain MHSD15 & MN093331 & Pantoea sp. MH769026 & 100 & 0.0 & 92.70 \\
\hline Bacillus sp. strain MHSD16 & MN078167 & Bacillus sp. EUC01244 & 99 & 0.0 & 90.96 \\
\hline Bacillus sp. strain MHSD17 & MN078168 & Bacillus cereus KJ935725 & 99 & 0.0 & $98.15 \%$ \\
\hline
\end{tabular}

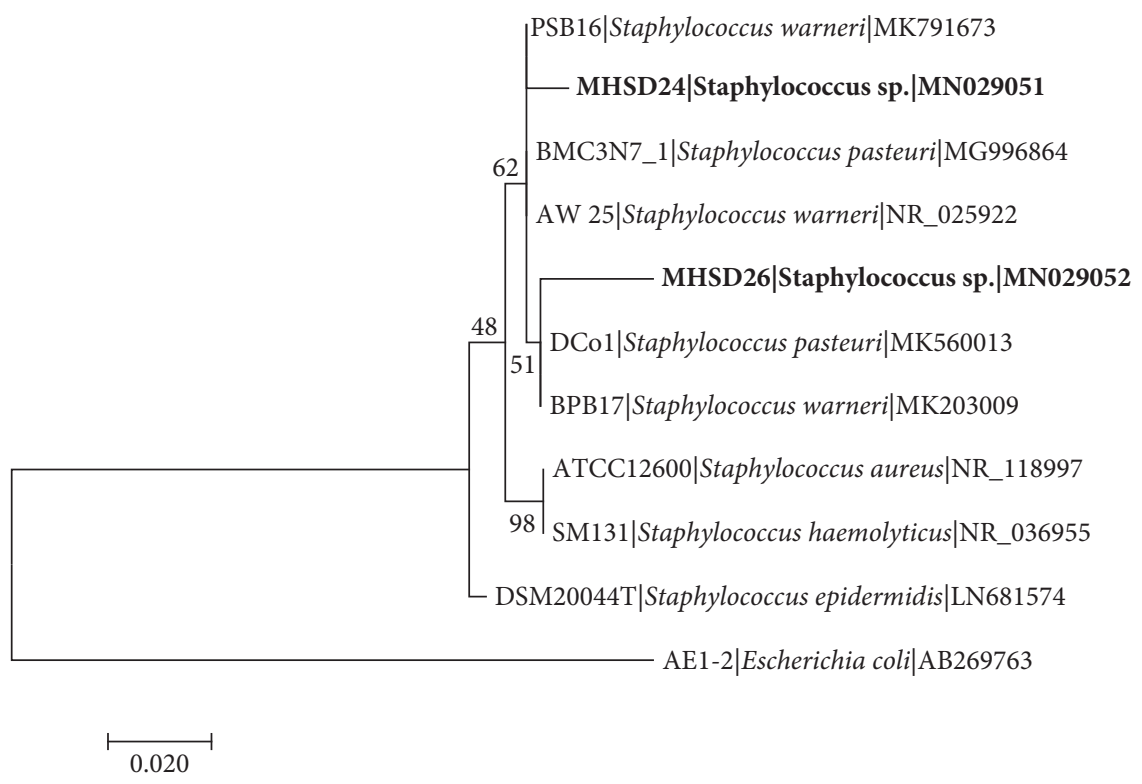

FIGURE 1: Maximum likelihood phylogenetic tree based on analysis of partial 16S rDNA nucleotide sequences of Staphylococcus sp. strain MHSD24 and MHSD26 with related strains from Staphylococcus genus. Numbers above or below the nodes indicate bootstrap values generated after 1000 replications. Escherichia coli AE-1 (AB269763) was used as an outgroup. 


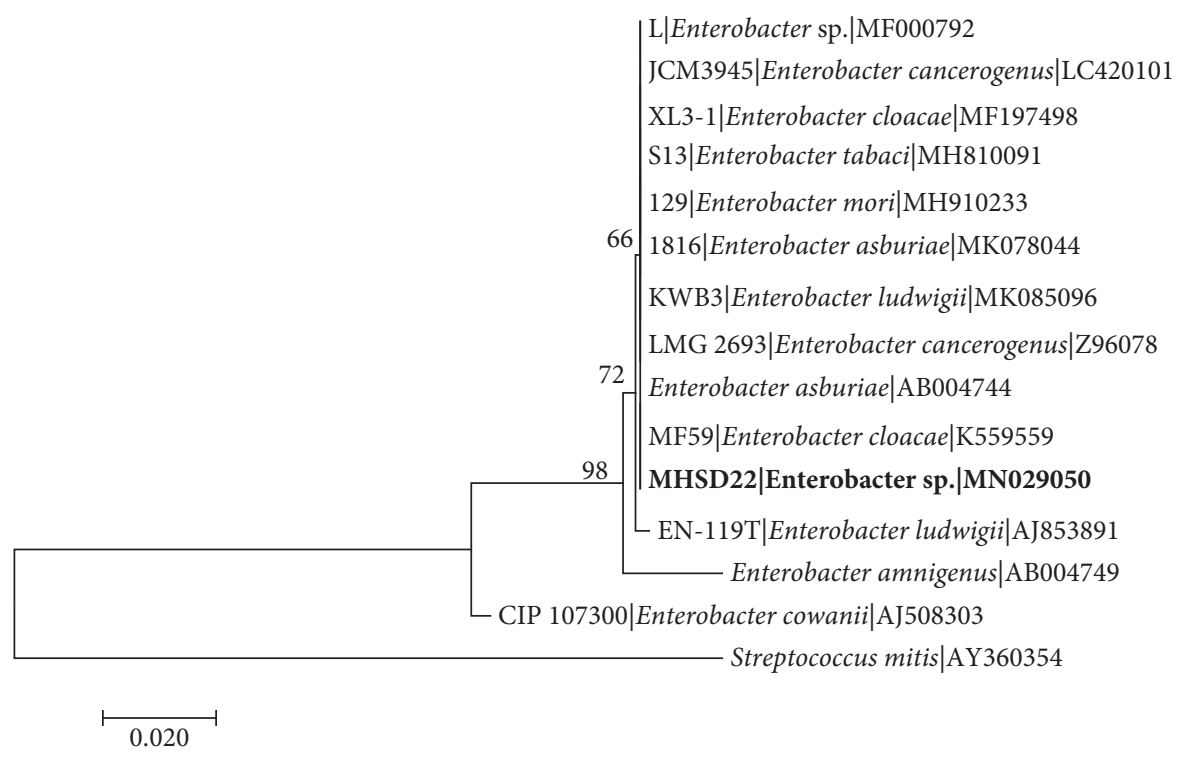

Figure 2: Maximum likelihood phylogenetic tree based on analysis of partial 16S rDNA nucleotide sequences of Enterobacter sp. strain MHSD22 with related strains from Enterobacter genus. Numbers above or below the nodes indicate bootstrap values generated after 1000 replications. Streptococcus mitis (AY360354) was used as an outgroup.

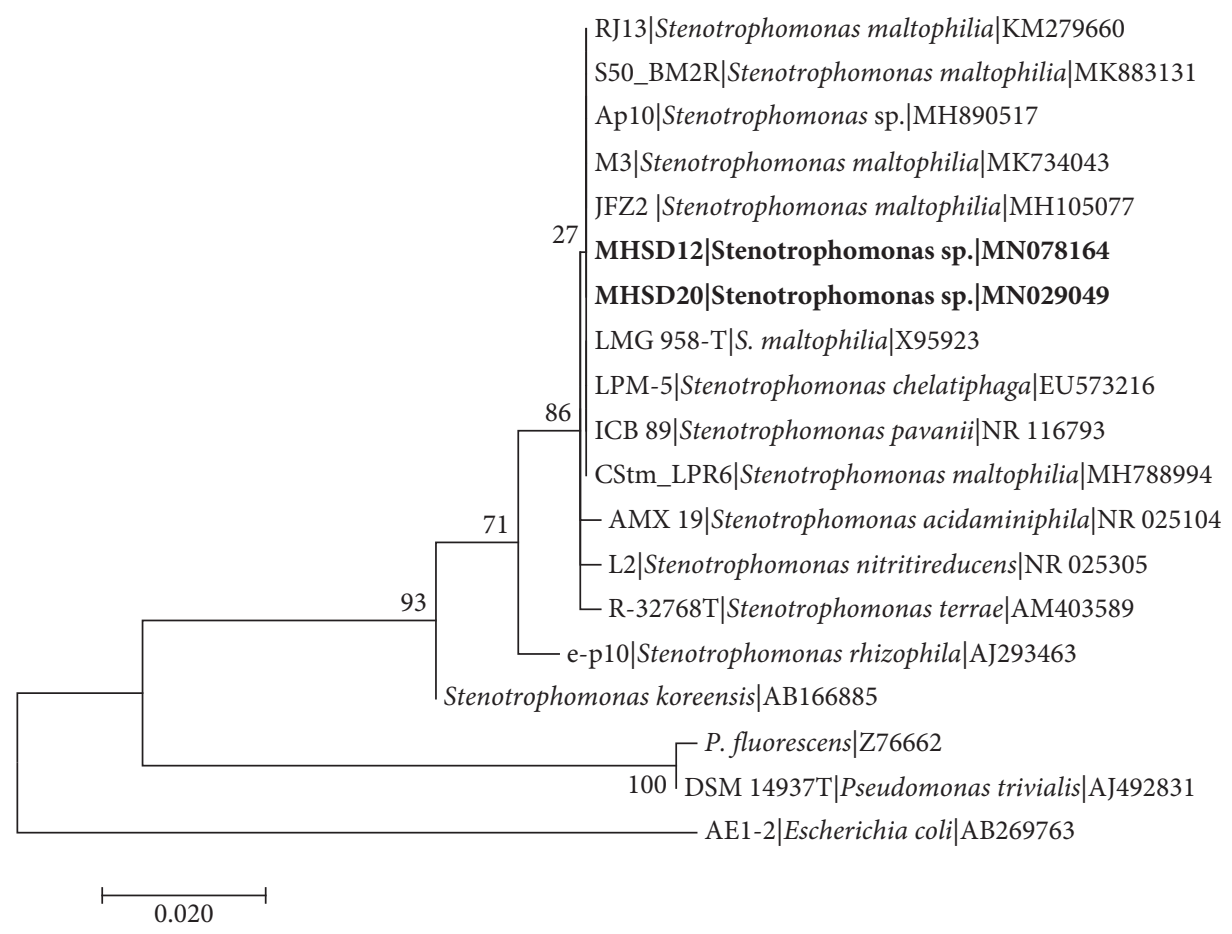

FIGURE 3: Maximum likelihood phylogenetic tree based on analysis of partial 16S rDNA nucleotide sequences of Stenotrophomonas sp. strain MHSD20 with related strains from Stenotrophomonas genus. Numbers above or below the nodes indicate bootstrap values generated after 1000 replications. Escherichia coli AE-1 (AB269763) was used as an outgroup.

for further species description and phylogenetic delineation. The $16 \mathrm{~S}$ rRNA gene has been recommended for identification of bacteria and this technique is regarded as the gold standard for species classification because the gene is ubiquitous in prokaryotes, containing approximately 1500 bases which are adequate for species analysis [25]. The $16 \mathrm{~S}$ RNA genes also consist of variable regions that enable comparison of species between distantly related species and $16 \mathrm{~S}$ rRNA gene is less likely to undergo horizontal gene transfer (HGT) [42]. Although the 16S rRNA gene is suitable for bacterial identification [26], many bacterial species cannot be differentiated by their 16S rRNA gene sequences as it gives high similarity between closely related species which is also indicated by the formation of polyphyletic 


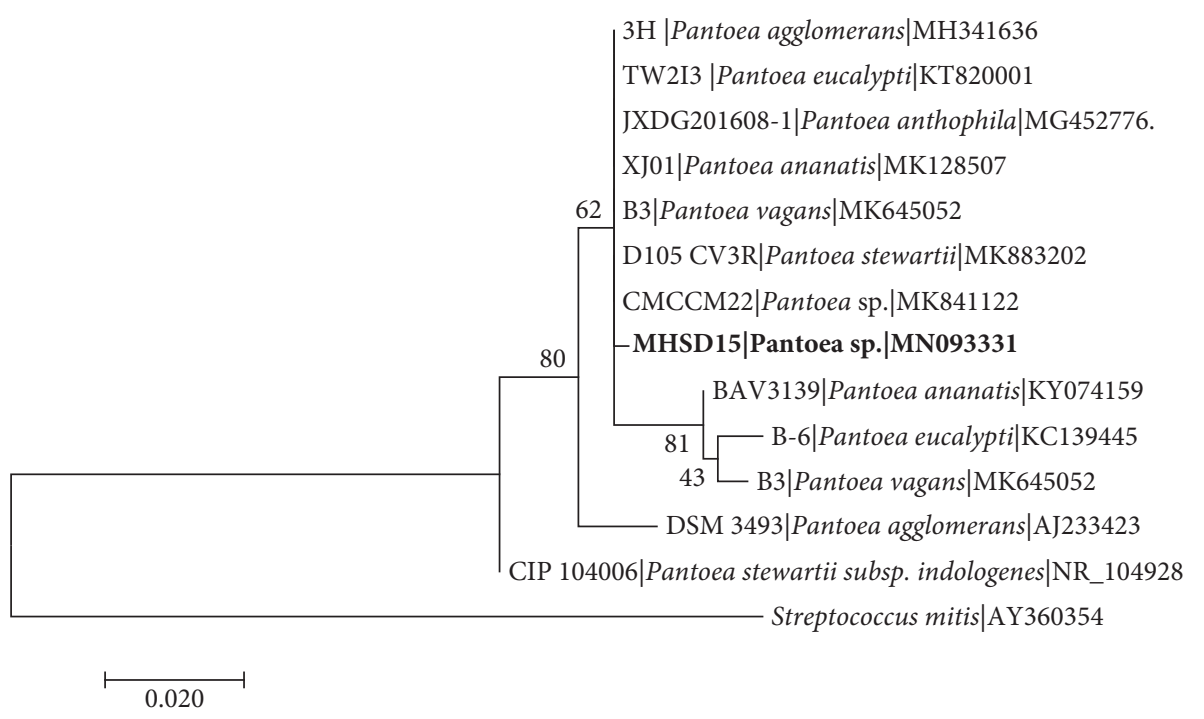

FIGURE 4: Maximum likelihood phylogenetic tree based on analysis of partial 16S rDNA nucleotide sequences of Pantoea sp. strain MHSD15 with related strains from Pantoea genus. Numbers above or below the nodes indicate bootstrap values generated after 1000 replications. Streptococcus mitis (AY360354) was used as an outgroup.

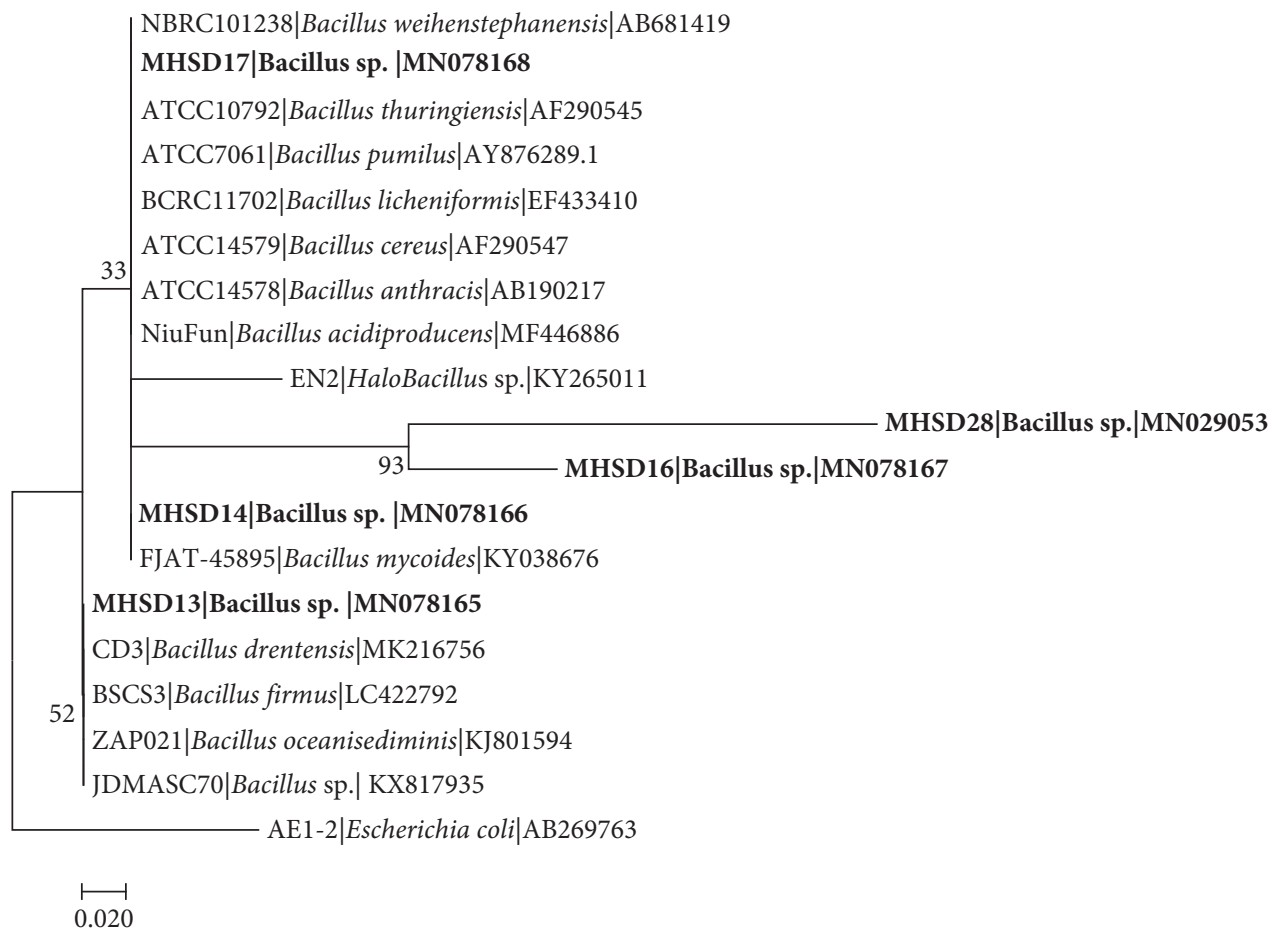

FIGURE 5: Maximum likelihood phylogenetic tree based on analysis of partial 16S rDNA nucleotide sequences of Bacillus sp. strain MHSD28. Bacillus sp. strain MHSD13. Bacillus sp. strain MHSD14, Bacillus sp. strain MHSD16, and Bacillus sp. strain MHSD17 with related strains from Bacillus genus. Numbers above or below the nodes indicate bootstrap values generated after 1000 replications. Escherichia coli AE-1 (AB269763) was used as an outgroup.

relationships on a phylogenetic tree [25]. Bacterial endophytes identified in this study formed polyphyletic relationship with closely related strains. In a separate study [27], based on phylogenomic analysis, it was indicated that Stenotrophomonas strain MHSD12 is closely related to Stenotrophomonas pavanii strain DSM 25135 which is an endophyte isolated from sugarcane [28].
3.3. Antibacterial Assay Using Minimum Inhibition Concentration. The antibacterial activity of endophytic bacteria's crude extracts was determined against five pathogenic test strains: Gram-negative bacteria Escherichia coli (ATCC25922), Pseudomonas aeruginosa (ATCC27853), and Klebsiella oxytoca (ATCC13182); Gram-positive bacteria Staphylococcus aureus (NCTC6571) and Bacillus cereus 
(ATCC10876). The MIC activity varied depending on the test strain used, most extracts showed interesting results, and the positive control Streptomycin at $1 \mathrm{mg} / \mathrm{mL}$ was effective against all the test strains. Minimum inhibition concentration of the extracted crude extracts from bacterial endophyte ranged from $0.312 \mathrm{mg} / \mathrm{mL}$ to $10 \mathrm{mg} / \mathrm{mL}$. The lowest MIC value was $0.312 \mathrm{mg} / \mathrm{mL}$ and other crude extracts indicated MIC values higher than $1 \mathrm{mg} / \mathrm{mL}$ as shown in Table 3.

Bacterial endophyte Stenotrophomonas sp. strain MHSD20 had MIC values ranging from $0.625 \mathrm{mg} / \mathrm{mL}$ to $5 \mathrm{mg} / \mathrm{mL}$, inhibiting $B$. cereus at $0.625 \mathrm{mg} / \mathrm{mL}$. Enterobacter sp. strain MHSD22 showed MIC values from $1.25 \mathrm{mg} / \mathrm{mL}$ to $10 \mathrm{mg} / \mathrm{mL}$ which were considered noninhibiting. The crude extract of Staphylococcus sp. strain MHSD26 had MIC concentration values ranging from $0.312 \mathrm{mg} / \mathrm{mL}$ to $10 \mathrm{mg} / \mathrm{mL}$, inhibiting B. cereus and S. aureus at 0.625 and $0.312 \mathrm{mg} / \mathrm{mL}$, respectively. Bacillus sp. strain MHSD28 showed MIC values ranging from $0.312 \mathrm{mg} / \mathrm{mL}$ to $10 \mathrm{mg} / \mathrm{mL}$, inhibiting $S$. aureus $0.312 \mathrm{mg} / \mathrm{mL}$ and E. coli at $0.625 \mathrm{mg} / \mathrm{mL}$. Crude extracts of Bacillus sp. strain MHSD14 had MIC values of $0.312 \mathrm{mg} / \mathrm{mL}$ to $5 \mathrm{mg} / \mathrm{mL}$ inhibiting S. aureus at $0.312 \mathrm{mg} / \mathrm{mL}$ and finally Pantoea sp. strain MHSD15 crude extracts had MIC values of $0.625 \mathrm{mg} /$ $\mathrm{mL}$ to $10 \mathrm{mg} / \mathrm{mL}$ inhibiting $S$. aureus at $0.625 \mathrm{mg} / \mathrm{mL}$. These findings are congruent with several studies, which revealed that endophytic bacteria have proven to be potential reliable sources of novel bioactive compounds with antimicrobial activity [10]. The MIC values of crude extracts $<1 \mathrm{mg} / \mathrm{mL}$ are classified to have significant antibacterial activity while extracts with $\mathrm{MIC}$ values $>1 \mathrm{mg} / \mathrm{mL}$ are classified as noninhibitors [29]. Most of the endophyte's crude extracts had significant inhibition values with the lowest MIC values $0.625 \mathrm{mg} / \mathrm{mL}$ and $0.312 \mathrm{mg} / \mathrm{mL}$. Enterobacter sp. strain MHSD22 did not have significant inhibition against all the test strains. The MIC values of the crude extracts at $0.625-0.325 \mathrm{mg} / \mathrm{mL}$ were significantly different $(p<0.05)$, with the exception of Enterobacter sp. strain MHSD22 which had MIC values higher than 1 against all test strains.

The difference in the inhibition between Gram-positive and Gram-negative may be due to variation in their cell wall structure. Gram-negative bacteria have an extra outer membrane, which could increase impermeability to antimicrobials. Similar results were observed in other studies [30]. The antibacterial activities of crude extracts of the bacterial endophytes obtained in this study provide evidence that endophytic bacteria could have potential in outcompeting pathogenic bacteria and this necessitates their use in drug discovery.

\subsection{Gas Chromatography High-Resolution Time-of-Flight Mass} Spectrometry Analysis. Bacterial endophytes are reported to produce same or similar bioactive compounds produced by the host plant [1], thus making them a promising source of novel molecules with various biotechnological applications. Dicoma anomala has ethnomedicinal history for the treatment of coughs, cold fever, and labour pains with pharmacological potential to antibacterial, anti-inflammatory, and antiplasmodial activities that could be a potential target for bioactive secondary metabolites studies [8]. Different classes of secondary metabolites such as phenolic acids, flavonoids, and triterpenes had previously been identified from $D$. anomala crude extracts [8]. In the current study, we identified 15 compounds from ethyl acetate crude extracts of bacterial endophytes isolated from D. anomala. Identification and characterization of secondary metabolites can lead to discovery of new compounds for drug development [31] including discovery of compounds that are of interest in food, cosmetic, and other industries. Most of the identified compounds in this study have been reported to possess interesting biological activities ranging from antimicrobial, antioxidant, and antiinflammatory as summarized in Table 4 . Benzyl benzoate is reported to function as fragrance ingredient, pesticides, $\mathrm{pH}$ adjusters, preservatives, solvents, and/or viscosity decreasing agents in cosmetic products [32]. Benzyl benzoate was identified in both Enterobacter sp. strain MHSD22 and Stenotrophomonas sp. strain MHSD12 bacterial endophytes extracts and it is reported to have antibacterial activity [33]. The identification of this compound indicates that, in addition to discovery of drug developments, bacterial endophytes are also useful for discovery of other bioactive compounds beneficial in food, cosmetic, and chemical industry [34]; this discovery necessitates further studies.

9-Octadecenamide, $(Z)$ - is an oleamide, an amide derived oleic acid biosynthesis that has shown antioxidative and hypolipidemic bioactivities [35]. It was previously identified from Bacillus crude extracts isolated from the rhizosphere of groundnut [36]. According to Cheng et al. [35], this compound was also reported as a potential medicinal treatment for mood and sleeping disorders; it was identified in Stenotrophomonas sp. strain MHSD12 and Pantoea sp. strain MHSD15 bacterial endophytes extracts. Hexadecane was identified in all bacterial endophyte extracts with Stenotrophomonas sp. strain MHSD20 as an exception. It is known to possess antifungal and antibacterial as well as antioxidant activity $[35,37]$. Pyrrolo[1,2-a] pyrazine-1,4-dione, hexahydro-3-(2-methylpropyl)- was identified in Staphylococcus sp. strain MHSD26, Enterobacter sp. strain MHSD22, and Bacillus sp. strain MHSD28 extracts and this compound has been reported as an antibiotic, anti-inflammatory, cholesterol reducing, and antitumor drug agent [38].

Heptacosane has been reported to have antioxidant properties [39] and was previously identified from Pseudomonas spp. isolated from Vigna radiate [40]. In the current study, heptacosane was identified from Bacillus sp. strain MHSD28, Bacillus sp. strain MHSD14, Stenotrophomonas sp. strain MHSD12, Staphylococcus sp. strain MHSD26, and Pantoea sp. strain MHSD15 extracts. Most of the compounds identified in this study have antimicrobial activity, which explains the significant antibacterial activity of the crude extracts. To our knowledge, this is the first study to report for the first time bacterial endophytes associated with $D$. anomala, with antimicrobial activity against bacterial pathogens and non-targeted profiling of their secondary metabolites. 
TABLE 3: Minimum inhibitory concentrations of crude extracts of secondary metabolites from bacterial endophytes associated with Dicoma anomala.

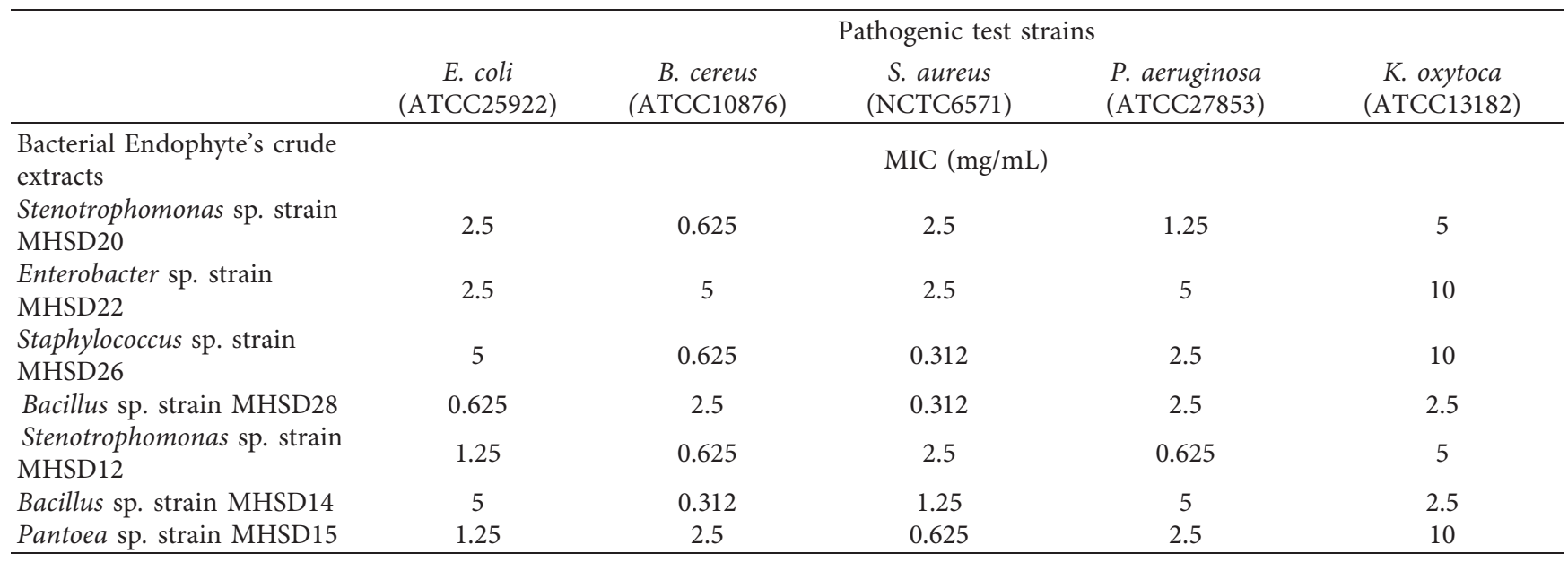

*Streptomycin (positive control) inhibited all the test strains at $1 \mathrm{mg} / \mathrm{mL}$.

TABLE 4: GC-HRTOFMS analysis bacterial endophyte's crude extracts associated with Dicoma anomala.

\begin{tabular}{|c|c|c|c|c|c|c|c|}
\hline $\mathrm{RT}_{(\min )}$ & $m / z$ & $\begin{array}{c}\text { Area } \\
\%\end{array}$ & $\begin{array}{l}\text { Molecular } \\
\text { formular }\end{array}$ & Name of the compound & Biological activity & $\begin{array}{l}\text { Bacterial } \\
\text { endophyte }\end{array}$ & References \\
\hline 15.51 & 212.0833 & 0.08 & $\mathrm{C}_{14} \mathrm{H}_{12} \mathrm{O}_{2}$ & Benzyl benzoate & $\begin{array}{l}\text { Fragrance ingredients, pesticides, } \mathrm{pH} \\
\text { adjusters, preservatives, solvents, and/ } \\
\text { or viscosity decreasing agents in } \\
\text { cosmetic products }\end{array}$ & E5, E2, & {$[32]$} \\
\hline 14.00 & 491.0536 & 0.32 & $\mathrm{C}_{16} \mathrm{H}_{48} \mathrm{O}_{8} \mathrm{Si}_{8}$ & $\begin{array}{l}\text { Cyclohexasiloxane, } \\
\text { dodecamethyl } \\
-\end{array}$ & Preservative & E5 & {$[41]$} \\
\hline 21.46 & 281.2712 & 0.11 & $\mathrm{C}_{19} \mathrm{H}_{36} \mathrm{O}_{2}$ & 9-Octadecenamide, $(\mathrm{Z})$ & $\begin{array}{l}\text { Antioxidative and hypolipidemic } \\
\text { bioactivity }\end{array}$ & E5, E7 & {$[35]$} \\
\hline 17.65 & 226.0927 & 0.89 & $\mathrm{C}_{16} \mathrm{H}_{34}$ & Hexadecane & $\begin{array}{c}\text { Antifungal, aAntibacterial, antioxidant } \\
\text { activity }\end{array}$ & $\begin{array}{l}\mathrm{E} 4, \mathrm{E} 6, \mathrm{E} 5 \\
\mathrm{E} 2, \mathrm{E} 3, \mathrm{E} 7\end{array}$ & {$[35,37]$} \\
\hline 17.38 & 208.1223 & 2.38 & $\mathrm{C}_{11} \mathrm{H}_{18} \mathrm{~N}_{2} \mathrm{O}_{2}$ & $\begin{array}{l}\text { Pyrrolo[1,2-a] pyrazine- } \\
\text { 1,4-dione, hexahydro-3-(2- } \\
\text { methylpropyl) }\end{array}$ & $\begin{array}{l}\text { Antibiotics, anti-inflammatory drugs, } \\
\text { cholesterol reducing drugs and } \\
\text { antitumor agents }\end{array}$ & E3, E2, E4 & {$[38]$} \\
\hline 17.76 & 549.0229 & 0.14 & $\mathrm{C}_{16} \mathrm{H}_{5} 0 \mathrm{O}_{7} \mathrm{Si}_{8}$ & $\begin{array}{c}\text { Octasiloxane, } 1,1,3,3,5,5 \\
7,7,9,9,11,11,13,13,15 \\
15 \\
\text {-hexadecamethyl- }\end{array}$ & Antimicrobial & E5, E2 & {$[38]$} \\
\hline 28.48 & 532.9910 & 0.19 & $\mathrm{C}_{16} \mathrm{H}_{48} \mathrm{O}_{6} \mathrm{Si}_{7}$ & $\begin{array}{l}\text { Heptasiloxane, } \\
\text { hexadecamethyl- }\end{array}$ & $\begin{array}{l}\text { Nematicide, antiantrogenic, } \\
\text { anticoranary, and antieczemic }\end{array}$ & $\begin{array}{l}\text { E5, E2, E7, } \\
\text { E1 }\end{array}$ & {$[42]$} \\
\hline 19.57 & 236.0503 & 0.00 & $\mathrm{C}_{14} \mathrm{H}_{18} \mathrm{O}_{4}$ & $\begin{array}{l}\text { Phthalic acid, methyl 2- } \\
\text { pentyl ester }\end{array}$ & $\begin{array}{l}\text { Plasticizers, phenol derivatives used for } \\
\text { flexibility and durability of plastic used } \\
\text { in cosmetics, perfumes, food } \\
\text { packaging, toys and medical devices, } \\
\text { antineoplastic and immunosuppressive }\end{array}$ & E5, & {$[43,44]$} \\
\hline 25.80 & 269.2484 & 0.09 & $\mathrm{C}_{16} \mathrm{H}_{22} \mathrm{O}_{4}$ & Dibutyl phthalate & $\begin{array}{l}\text { Antifungal, antibacterial, antiviral, and } \\
\text { antioxidant activities }\end{array}$ & $\begin{array}{l}\mathrm{E} 4, \mathrm{E} 6, \mathrm{E} 5 \\
\mathrm{E} 2\end{array}$ & {$[45]$} \\
\hline 8.33 & 117.0574 & 0.32 & $\mathrm{C}_{8} \mathrm{H}_{7} \mathrm{~N}$ & Indole & $\begin{array}{l}\text { Anti-inflammatory and analgesic } \\
\text { agents }\end{array}$ & $\begin{array}{l}\text { E4, E6, E5, } \\
\text { E2, E3, E7 }\end{array}$ & {$[46]$} \\
\hline 18.00 & 283.3320 & 0.69 & $\mathrm{C}_{27} \mathrm{H}_{56}$ & Heptacosane & Antioxidant activity & $\begin{array}{l}\text { E7, E3, E5, } \\
\text { E6, E4 }\end{array}$ & [39] \\
\hline 17.98 & 280.3130 & 0.03 & $\mathrm{C}_{20} \mathrm{H}_{40}$ & 9-Eicosene & Antimicrobial and cytotoxic properties & E3, E5, E6 & [47] \\
\hline 11.97 & 194.0939 & 0.04 & $\mathrm{C}_{11} \mathrm{H}_{14} \mathrm{O}_{3}$ & $\begin{array}{l}\text { Benzoic acid, 4-ethoxy-, } \\
\text { ethyl ester }\end{array}$ & Antimicrobial preservative & E5, E7, E6 & {$[48]$} \\
\hline 19.44 & 287.9506 & 0.03 & $\mathrm{C}_{12} \mathrm{H}_{7} \mathrm{Cl}_{3} \mathrm{O}_{2}$ & Triclosan & Antimicrobial & $\begin{array}{l}\text { E6, E2, E3, } \\
\text { E7 }\end{array}$ & {$[49]$} \\
\hline
\end{tabular}


TABLE 4: Continued.

\begin{tabular}{|c|c|c|c|c|c|c|c|}
\hline $\mathrm{RT}_{(\min )}$ & $m / z$ & $\begin{array}{c}\text { Area } \\
\%\end{array}$ & $\begin{array}{c}\text { Molecular } \\
\text { formular }\end{array}$ & Name of the compound & Biological activity & $\begin{array}{c}\text { Bacterial } \\
\text { endophyte }\end{array}$ & References \\
\hline 6.21 & 99.0316 & 0.24 & $\mathrm{C}_{4} \mathrm{H}_{5} \mathrm{NO}_{2}$ & Succinimide & $\begin{array}{l}\text { CNS depressant, analgesic, antitumor, } \\
\text { cytostatic, anorectic, nerve conduction } \\
\text { blocking, antispasmodic, bacteriostatic, } \\
\text { muscle relaxant, hypotensive, } \\
\text { antibacterial, antifungal, } \\
\text { anticonvulsant and antitubercular }\end{array}$ & E7 & {$[50]$} \\
\hline
\end{tabular}

RT $(\mathrm{m})=$ retention time (minutes), $\mathrm{m} / z=$ mass-to-charge ratio, $\mathrm{E} 1 *($ Stenotrophomonas sp. strain MHSD20), E2 $*($ Enterobacter sp. strain MHSD22), E3*(Staphylococcus sp. strain MHSD26), E4*(Bacillus sp. strain MHSD28), E5*(Stenotrophomonas sp. strain MHSD12), E6*(Bacillus sp. strain MHSD14), E7*(Pantoea sp. strain MHSD15).

\section{Conclusions}

Based on the results, we conclude that $D$. anomala does harbor diverse types of endophytic bacteria. Moreover, antimicrobial activity of these endophytes' crude extracts was significant against pathogenic strains. Further investigation should be conducted to isolate biologically active compounds from bacterial endophytes with antimicrobial activity for drug development and use in other industries such as food and cosmetics.

\section{Data Availability}

The 16S rRNA gene data of this study are available from the corresponding author upon request. The reported bacterial endophytes in this study have been deposited in GenBank with the following accession numbers: MN029049, MN029050, MN029051, MN029052, MN029053, MN078164, MN078165, MN078166, MN093331, MN078167, and MN078168.

\section{Disclosure}

This study is based on the M.Sc. dissertation work of Ms. SC Makuwa.

\section{Conflicts of Interest}

The authors declare that they have no conflicts of interest regarding the publication of this paper.

\section{Acknowledgments}

Thanks are due to South African National Research Foundation, Thuthuka (grant no. TTK170405225920), and University of Johannesburg, Faculty of Science, for the financial support for the study. Ms. SC Makuwa received DAAD-NRF joint in country scholarship (grant number: SFH180523334030) and University of Johannesburg, Faculty of Science Merit bursary.

\section{References}

[1] A. Alvin, K. I. Miller, and B. A. Neilan, "Exploring the potential of endophytes from medicinal plants as sources of antimycobacterial compounds," Microbiological Research, vol. 169, no. 7-8, pp. 483-495, 2014.
[2] A. Gurib-Fakim, "Medicinal plants: traditions of yesterday and drugs of tomorrow," Molecular Aspects of Medicine, vol. 27, no. 1, pp. 1-93, 2006.

[3] B. Jasim, C. John Jimtha, M. Jyothis, and E. K. Radhakrishnan, "Plant growth promoting potential of endophytic bacteria isolated from Piper nigrum," Plant Growth Regulation, vol. 71, no. 1, pp. 1-11, 2013.

[4] P. Golinska, M. Wypij, G. Agarkar, D. Rathod, H. Dahm, and M. Rai, "Endophytic actinobacteria of medicinal plants: diversity and bioactivity," Antonie van Leeuwenhoek, vol. 108, no. 2, pp. 267-289, 2015.

[5] J. E. John, "Natural products as lead-structures: a role for biotechnology," Drug Discovery Today, vol. 15, pp. 11-12, 2010.

[6] D. J. Newman and G. M. Cragg, "Natural products as sources of new drugs over the 30 years from 1981 to 2010," Journal of Natural Products, vol. 75, no. 3, pp. 311-335, 2012.

[7] H. Yu, L. Zhang, L. Li et al., "Recent developments and future prospects of antimicrobial metabolites produced by endophytes," Microbiological Research, vol. 165, no. 6, pp. 437-449, 2010.

[8] J. V. M. Becker, M. M. van Der Merwe, A. C. van Brummelen et al., "In vitro anti-plasmodial activity of Dicoma anomala Subsp. gerrardii (Asteraceae): identification of its main active constituent, structure-activity relationship studies and gene expression profiling," Malaria Journal, vol. 10, Article ID 295, 2011.

[9] South African National Biodiversity Institute (SANBI), 2019, http://pza.sanbi.org/dicoma-anomala.

[10] A. Maroyi, "Dicoma anomala sond.: a review of its botany, ethnomedicine, phytochemistry and pharmacology," Asian Journal of Pharmaceutical and Clinical Research, vol. 11, no. 6, pp. 70-77, 2018.

[11] P. N. Patle, N. P. Navnage, and P. R. Ramteke, "Endophytes in plant system: roles in growth promotion, mechanism and their potentiality in achieving agriculture sustainability," International Journal of Chemical Studies, vol. 6, pp. 270-274, 2018.

[12] C. Yeates, M. R. Gillings, A. D. Davison, N. Altavilla, and D. A. Veal, "PCR amplification of crude microbial DNA extracted from soil," Letters in Applied Microbiology, vol. 25, no. 4, pp. 303-307, 1997.

[13] T. A. Hall, "BioEdit: a user-friendly biological sequence alignment editor and analysis program for windows 95/98/ NT," Nucleic Acids Symposium Series, vol. 41, pp. 95-98, 1999.

[14] S. Kumar, G. Stecher, and K. Tamura, "MEGA7: molecular evolutionary genetics analysis version 7.0 for bigger datasets," Molecular Biology and Evolution, vol. 33, no. 7, pp. 1870-1874, 2016. 
[15] K. Tamura and M. Nei, "Estimation of the number of nucleotide substitutions in the control region of mitochondrial DNA in humans and chimpanzees," Molecular Biology and Evolution, vol. 10, no. 3, pp. 512-526, 1993.

[16] J. M. Andrews, "Determination of minimum inhibitory concentrations," Journal of Antimicrobial Chemotherapy, vol. 48, no. 1, pp. 5-16, 2001.

[17] S. Kim, J. Chen, T. Cheng et al., "PubChem 2019 update: improved access to chemical data," Nucleic Acids Research, vol. 8, pp. 1102-1109, 2019.

[18] D. A. Filimonov, A. A. Lagunin, T. A. Gloriozova et al., "Prediction of the biological activity spectra of organic compounds using the pass online web resource," Chemistry of Heterocyclic Compounds, vol. 50, no. 3, pp. 444-457, 2014.

[19] G. V. de Melo Pereira, K. T. Magalhães, E. R. Lorenzetii, T. P. Souza, and R. F. Schwan, "A multiphasic approach for the identification of endophytic bacterial in strawberry fruit and their potential for plant growth promotion," Microbial Ecology, vol. 63, no. 2, pp. 405-417, 2012.

[20] H. Panchal and S. S. Ingle, "Isolation and characterization of endophytes from the root of medicinal plant Chlorophytum borivilianum (Safed musli)," Journal of Advanced Research and Development, vol. 2, pp. 205-209, 2011.

[21] S. Taghavi, C. Garafola, S. Monchy et al., "Genome survey and characterization of endophytic bacteria exhibiting a beneficial effect on growth and development of poplar trees," Applied and Environmental Microbiology, vol. 75, no. 3, pp. 748-757, 2009.

[22] V. J. Szilagyi-Zecchin, A. C. Ikeda, M. Hungria et al., "Identification and characterization of endophytic bacteria from corn (zea mays L.) roots with biotechnological potential in agriculture," AMB Express, vol. 4, Article ID 26, 2014.

[23] X. Q. Xiong, H. D. Liao, J. S. Liu et al., "Isolation of a rice endophytic bacterium, Pantoea sp. Sd-1, with ligninolytic activity and characterization of its rice straw degradation ability," Letters in Applied Microbiology, vol. 58, no. 2, pp. 123-129, 2013.

[24] P. R. Hardoim, L. S. van Overbeek, G. Berg et al., "The hidden world within plants: ecological and evolutionary considerations for defining functioning of microbial endophytes," Microbiology and Molecular Biology Reviews, vol. 79, no. 3, pp. 293-320, 2015.

[25] K. Kitahara and K. Miyazaki, "Revisiting bacterial phylogeny: natural and experimental evidence for horizontal gene transfer of 16S rRNA," Mobile Genetic Elements, vol. 3, Article ID e24210, 2013.

[26] A. J. Sabat, E. van Zanten, V. Akkerboom et al., "Targeted next-generation sequencing of the 16S-23S rRNA region for culture-independent bacterial identification-increased discrimination of closely related species," Scientific Reports, vol. 7, Article ID 3434, 2017.

[27] P. M. Maela and M. H. Serepa-Dlamini, "Draft genome sequence of Stenotrophomonas pavanii strain MHSD12, a bacterial endophyte associated with Dicoma anomala," Microbiology Resource Announcements, vol. 9, Article ID e00550, 2020.

[28] P. L. Ramos, S. van Trappen, F. L. Rocha et al., "Screening for endophytic nitrogen-fixing bacteria in Brazilian sugar cane varieties used in organic farming and description of Stenotrophomonas pavanii sp. nov," International Journal of Systematic and Evolutionary Microbiology, vol. 61, no. 4, pp. 926-931, 2011.
[29] S. F. van Vuuren, "Antimicrobial activity of South African medicinal plants," Journal of Ethnopharmacology, vol. 119, no. 3, pp. 462-472, 2008.

[30] M. B. Ticho, T. Morris, M. Meyer et al., "Antibacterial activity of rationally designed antimicrobial peptides," International Journal of Microbiology, vol. 2020, Article ID 2131535, 9 pages, 2020.

[31] P. Chikezie, C. Ibegbulem, and F. Mbagwu, "Medicinal \& aromatic plants medicinal potentials and toxicity concerns of bioactive principles," Medicinal \& Aromatic Plants, vol. 4, no. 3, pp. 1-15, 2015.

[32] W. Johnson, W. F. Bergfeld, D. V. Belsito et al., "Safety assessment of benzyl alcohol, benzoic acid and its salts, and benzyl benzoate," International Journal of Toxicology, vol. 36, no. 3, pp. 5S-30S, 2017.

[33] H. Diastuti, M. Chasani, and S. Suwandri, "Antibacterial activity of benzyl benzoate and crotepoxide from Kaempferia rotunda L. Rhizome," Indonesian Journal of Chemistry, vol. 20, no. 1, pp. 9-15, 2020.

[34] M. Singh, A. Kumar, R. Singh, and K. D. Pandey, "Endophytic bacteria: a new source of bioactive compounds," 3 Biotech, vol. 7, pp. 1-14, 2017.

[35] A. B. Hsouna, M. Trigui, R. B. Mansour, R. M. Jarraya, M. Damak, and S. Jaoua, "Chemical composition, cytotoxicity effect and antimicrobial activity of Ceratonia siliqua essential oil with preservative effects against Listeria inoculated in minced beef meat," International Journal of Food Microbiology, vol. 148, no. 1, pp. 66-72, 2011.

[36] A. A. Bharose and H. P. Gajera, "Antifungal activity and metabolites study of Bacillus strain against aflatoxin producing Aspergillus," Journal of Applied Microbiology and Biochemistry, vol. 2, no. 2, pp. 1-8, 2018.

[37] S. Yogeswari, S. N. Ramalakshmi, J. M. Muthu et al., "Identification and comparative studies of different volatile fractions from Monochaetia kansensis by GC-MS," Global Journal of Pharmacology, vol. 6, pp. 65-71, 2012.

[38] M. R. K. Rao, N. V. Lakshmi, and L. Sundaram, "Preliminary phytochemical and GC MS analysis of different extracts of psophocarpus tetragonolobus leaves," Journal of Pharmaceutical Sciences, vol. 5, 2018.

[39] A. Akpuaka, M. M. Ekwenchi, D. A. Dashak et al., "Biological activities of characterized isolates of $\mathrm{N}$-hexane extract of Azadirachta indica A.juss (neem) leaves," New York Science Journal, vol. 6, pp. 119-124, 2013.

[40] P. Jishma, N. Hussain, R. Chellappan, R. Rajendran, J. Mathew, and E. K. Radhakrishnan, "Strain-specific variation in plant growth promoting volatile organic compounds production by five different Pseudomonas spp. as confirmed by response of Vigna radiata seedlings," Journal of Applied Microbiology, vol. 123, no. 1, pp. 204-216, 2017.

[41] J. Rani and S. Giri, "Screening of bio-active compounds and anticancer activity of Punica granatum L," World Journal of Science and Research, vol. 1, pp. 6-15, 2016.

[42] M.-C. Cheng, Y.-B. Ker, T.-H. Yu, L.-Y. Lin, R. Y. Peng, and C.-H. Peng, "Chemical synthesis of $9(Z)$-Octadecenamide and its hypolipidemic effect: a bioactive agent found in the essential oil of mountain celery seeds," Journal of Agricultural and Food Chemistry, vol. 58, no. 3, pp. 1502-1508, 2010.

[43] D.-Y. Bang, I.-K. Lee, and B.-M. Lee, "Toxicological characterization of phthalic acid," Toxicological Research, vol. 27, no. 4, pp. 191-203, 2011.

[44] P. Kushwaha, S. S. Yadav, V. Singh et al., "Phytochemical screening and GC-MS studies of the methanolic extract of 
Tridax procumbens," International Journal of Pharmaceutical Sciences and Research, vol. 10, pp. 2492-2496, 2019.

[45] Y. Hong, S. Huang, J. Wu et al., "Identification of essential oils from the leaves of 11 species of Eriobotrya," Pakistan Journal of Botany, vol. 42, pp. 4379-4386, 2010.

[46] V. Sharma, P. Kumar, and D. Pathak, "Biological importance of the indole nucleus in recent years: a comprehensive review," Journal of Heterocyclic Chemistry, vol. 47, pp. 491-502, 2010.

[47] M. Mulyono, B. W. Lay, O. L. Laora et al., “Antidiarrheal activity of apus bamboo (Gigantochloa apus) leaf extract and its bioactive compounds," American Journal of Microbiology, vol. 4, no. 1, pp. 1-8, 2013

[48] I. F. Begum, R. Mohankumar, M. Jeevan et al., "GC-MS analysis of bio-active molecules derived from paracoccus pantotrophus FMR19 and the antimicrobial activity against bacterial pathogens and MDROs," Indian Journal of Microbiology, vol. 56, pp. 426-432, 2016.

[49] M. A. Alfhili and M. H. Lee, "Triclosan: an update on biochemical and molecular mechanisms," Oxidative Medicine and Cellular Longevity, vol. 2019, Article ID 1607304, 28 pages, 2019.

[50] M. M. Patil and S. S. Rajput, "Succinimides: synthesis, reaction and biological activity," International Journal of Pharmacy and Pharmaceutical Sciences, vol. 6, pp. 8-14, 2014. 